\title{
Perspective of placenta derived mesenchymal stem cells in acute liver failure
}

\author{
Mahshid Saleh', Mohammad Taher ${ }^{2}$, Amir Ali Sohrabpour ${ }^{3}$, Amir Abbas Vaezi ${ }^{4}$, Mohsen Nasiri Toosi ${ }^{5}$, \\ Maria Kavianpour ${ }^{1}$, Zeinab Ghazvinian ${ }^{1}$, Shahrokh Abdolahi ${ }^{1}$ and Javad Verdi ${ }^{{ }^{*}}$
}

\begin{abstract}
Acute Liver failure (ALF) is a life-threatening disease and is determined by coagulopathy (with INR $\geq 1.5$ ) and hepatic encephalopathy as a result of severe liver injury in patients without preexisting liver disease. Since there are problems with liver transplantation including lack of donors, use of immunosuppressive drugs, and high costs of this process, new therapeutic approaches alongside current treatments are needed. The placenta is a tissue that is normally discarded after childbirth. On the other hand, human placenta is a rich source of mesenchymal stem cells (MSCs), which is easily available, without moral problems, and its derived cells are less affected by age and environmental factors. Therefore, placenta-derived mesenchymal stem cells (PD-MSCs) can be considered as an allogeneic source for liver disease. Considering the studies on MSCs and their effects on various diseases, it can be stated that MSCs are among the most important agents to be used for novel future therapies of liver diseases. In this paper, we will investigate the effects of mesenchymal stem cells through migration and immigration to the site of injury, cell-to-cell contact, immunomodulatory effects, and secretory factors in ALF.
\end{abstract}

Keywords: Acute liver failure, Mesenchymal stem cells, Placenta, Cell therapy

\section{Introduction}

Liver is one of the largest vital organs in human body that controls various biological processes, including the production of multiple hormones, storage of glycogen, neutralization of toxins and drugs, control of metabolism, metabolism of urea, and synthesis of plasma protein. Typically, most physiological features of liver function are controlled by liver cells or hepatocytes; therefore, the loss of hepatocytes is the main cause of liver failure. Several diseases related to malfunction of the liver are caused by damage to or loss of hepatocytes, including viral hepatitis, fatty liver disease, drug and toxin-induced liver injury, hepatocellular carcinoma, and hepatic abnormalities associated with autoimmunity and cirrhosis [1].

\footnotetext{
*Correspondence: JavadVerdi2019@gmail.com

${ }^{1}$ Department of Tissue Engineering and Applied Cell Sciences, School of Advanced Technologies in Medicine, Tehran University of Medical Sciences, Tehran, Iran

Full list of author information is available at the end of the article
}

In adults, the liver weighs nearly $1.4 \mathrm{~kg}(3.1 \mathrm{lb})$ and lies to the right of the abdomen below the diaphragm [2]. Each year, many people worldwide develop liver disease. Acute liver injury (ALI), acute liver failure (ALF), acute on chronic liver failure (CLF), and inherited metabolic liver diseases are examples of liver diseases [3].

\section{Liver failure}

Liver failure is a clinical syndrome diagnosed with clinical signs of jaundice, ascites, hepatic encephalopathy and a tendency for bleeding due to liver damage. This syndrome can occur for a variety of reasons, including viral hepatitis, autoimmune hepatitis and liver damage [4]. Approximately 1.6 cases per million people worldwide develop this serious disease annually, which in turn results in high costs and mortality $[5,6]$. Patients with drug induced liver injury are associated with some degree of ascites, encephalopathy, coagulopathy of any grade (PT (prothrombin time), INR (international normalized ratio)) as well as impaired liver function (AST

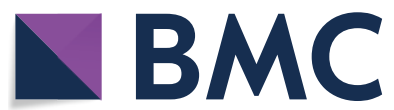

(c) The Author(s) 2020. This article is licensed under a Creative Commons Attribution 4.0 International License, which permits use, sharing, adaptation, distribution and reproduction in any medium or format, as long as you give appropriate credit to the original author(s) and the source, provide a link to the Creative Commons licence, and indicate if changes were made. The images or other third party material in this article are included in the article's Creative Commons licence, unless indicated otherwise in a credit line to the material. If material is not included in the article's Creative Commons licence and your intended use is not permitted by statutory regulation or exceeds the permitted use, you will need to obtain permission directly from the copyright holder. To view a copy of this licence, visit http://creativeco mmons.org/licenses/by/4.0/. The Creative Commons Public Domain Dedication waiver (http://creativecommons.org/publicdomain/ zero/1.0/) applies to the data made available in this article, unless otherwise stated in a credit line to the data. 
(aspartate aminotransferase), ALT(alanine transaminase), TBIL (Total bilirubin Indirect level), ALB (Albumin)). Liver failure is divided into three forms as follows. ALF within $48 \mathrm{~h}$ to several days with jaundice, coagulopathy and encephalopathy; acute-on-chronic liver failure (ACLF) with a background of chronic liver disease leading to rapid progression of liver injury and associated with jaundice and ascites; and CLF occurring within months to years [7].

\section{Acute liver failure (ALF)}

ALF is an unpredictable and potentially catastrophic condition often encountered in intensive care units, with more than 2500 cases reported each year in the United States. The progression potential of acute hepatic dysfunction toward multi-organ failure demands rapid diagnosis and management of the disease. Due to a set of hepatic and non-hepatic complications, ALF indirectly leads to immediate follow-up for liver transplantation [8]. ALF, formerly known as fulminant hepatic failure, means the development of hepatocellular disorders such as coagulopathy and encephalopathy with INR $\geq 1.5$ in patients without a history of liver disease within 26 weeks. More than half of the cases of ALF progression require liver transplantation and significant improvements have been reported in the last decade after liver transplantation. ALF mortality is usually due to intracranial hypertension $(\mathrm{ICH})$ and infection [9-11]). However, patients with varying degrees of hemodynamic disorders and renal failure have also been reported [12, 13]. Clinically, the patients show coagulopathy, jaundice and hepatic encephalopathy. The period between the onset of the first clinical symptoms and hepatic encephalopathy is crucial in determining the prognosis of these patients $[14,15]$. There are obvious differences in the development mechanisms of early ALF. The three main factors determining the prognosis of this disease include metabolic problems leading to the loss of liver cells, secretion of toxins and mediators from the liver tissue, and capacity of the remaining hepatocytes to repair the liver $[15$, $16]$.

Common treatments are therapies that are often meant to improve the complications of acute liver failure (ALF). Multiple organ failure (MOF) and severe infection are the most prevalent factors of mortality in these patients. Therefore, management of treatment for ALF patients should focus on the handling and prevention of infection [17]. ALF patients with severe hepatic encephalopathy, those with renal failure and patients who have any of SIRS criteria use broad-spectrum antibiotics [18]. Application of vasoconstrictors and dialysis reduce the incidence of cerebral edema [19]. In case of hepatic encephalopathy, the patient is transferred to ICU and ventilator devices are used to regulate the level of blood gases patients with ALF have qualitative and quantitative coagulation abnormalities. In control of bleeding and during invasive procedures, there is indication for FFP and platelet administration [20]. To prevent gastrointestinal bleeding in ALF, patients admitted to ICU are treated with $\mathrm{H} 2$ blockers or proton pump inhibitors (PPI) [21]. Patients with ALF are at risk of hypovolemia for a number of reasons, including poor oral fluid intake, vomiting, and vasodilation, in which case bolus fluids are used and level of fluids is frequently maintained if necessary to keep serum sodium levels and prevent fluid overload [22]. In addition to the mentioned treatments, $10-20 \%$ glucose is administered when glycemic target is $140 \mathrm{mg} / \mathrm{dL}$ and $\mathrm{Na}$ level is $135-145 \mathrm{mmol} / \mathrm{L}$, as well as $\mathrm{N}$-acetylcysteine and stress ulcer prophylaxis agents [17].

\section{Etiology}

A wide variety of factors cause ALF (Table 1) [23-25]. The most common causes of this disease are viral infections and drug-induced liver inflammation. In Asia and parts of Europe, mainly viral hepatitis agents are involved and acetaminophen is the predominant factor in countries such as USA and Australia [26].

\section{Table 1 Etiology of ALF}

\begin{tabular}{lc}
\hline Other etiologies of ALF & The most common global agents of ALF \\
\hline Hypoxia-induced liver injury & Viral hepatitis \\
Acute Budd-Chiari Syndrome & Drug-induced hepatitis \\
Veno-occlusive Disease & \\
Wilson's disease & \\
Mushroom Ingestion & \\
Sepsis & \\
Autoimmune hepatitis & \\
Acute fatty liver of pregnancy & \\
HELLP (hemolysis, elevated liver enzymes, low platelet) syndrome &
\end{tabular}




\section{Immune system in patients with ALF}

Impaired function of both humoral and innate immunity is implicated in the pathophysiology of ALF [27].

The mechanism of ALF begins with necrosis of hepatocytes [28]. Oxidative stress is triggered when liver injury is caused by factors such as viral infections, alcohol consumption, drug intoxication, autoimmune diseases, herbal remedies and many other factors [29-31]. Oxidative stress results in the production of reactive oxygen species, which in turn activates the Janus kinase (JNK) signaling pathway [32] and generates damageassociated molecular patterns (DAMPs), followed by liver inflammation. Liver inflammation is a major factor in immunopathology of several hepatic diseases [33, 34]. DAMPs activate hepatic macrophages (Kupffer cells (KCs)) and induce the formation of inflammasome $[32,35]$ that eventually leads to the secretion of IL-1, IL-18, and caspase 1 [32]. DAMPs are detected by Kupffer cells $[33,36]$ that express a large number of DAMP receptors, including TLR4, TLR9, and RAGE [36]. KCs are activated in this process and release inflammatory cytokines such as TNF $\alpha$, oxygen radicals, and chemokines such as CCL2 under the effect of inflammatory signals. The presence of inflammatory factors mobilizes inflammatory cells such as neutrophils and monocytes and thereby increases inflammation $[33,34]$.

\section{Hepatic encephalopathy in ALF}

Hepatic encephalopathy (HE) is a function of neurotoxins that reach the brain through the bloodstream [37]. Various factors such as blood ammonia levels, infection, necrotic liver, toxins, and systemic inflammatory response syndrome (SIRS) can lead to HE [38]. In normal conditions, the ammonia produced in the body is efficiently excreted by the liver through the urea cycle and glutamine synthesis and thus a small amount of ammonia remains in hepatic vessels. In ALF, ammonia levels rise in the hepatic vein, and the liver loses the ability to release ammonia from the hepatic veins. The muscles and brain begin ammonia detoxification through glutamine synthesis. Therefore, both of these tissues are considered as an ammonia scavenging and glutamine releasing organs [39].

Tissue damage is the first factor triggering SIRS reaction. As explained above, the injury leads to the release of inflammatory mediators such as DAMPS, TNF $\alpha$, IL-6, and IL-18. Inflammatory cells such as lymphocytes and monocytes reach the damage site and enhance the inflammatory response. Coagulation factors as well as primary and secondary homeostasis also become involved and result in SIRS reaction [38]. These reactions are associated with the development of $\mathrm{HE}[40,41]$, bacteremia [42] and, in some cases, infection [41, 43].

Compensatory anti-inflammatory response syndrome (CARS) occurs in reaction to SIRS, leading to the secretion of anti-inflammatory factors (including IL-10 and SPLI) from hepatic macrophages during the early stages. This reaction is meant to alleviate the inflammatory status $[44,45]$. Both of these reactions eventually lead to dysregulation of the immune system and defective immune responses to microbial agents [46, 47].

\section{Mesenchymal stem cells and their secreted factors}

MSCs are fusiform non-hematopoietic cells capable of adhering to plastic surfaces, which can be isolated from various tissues, including placenta, umbilical cord, bone marrow, adipose, and other tissues [48].

Despite their morphological and phenotypical similarities, MSCs have different regeneration potentials [49], which is due to the microenvironment and cellular niches affecting their fate [50]. The number of stem cells in many adult tissues is small and isolation of them is associated with several risks; for example, the cells exhibit a limited capacity for differentiation and proliferation after removal from the body, making it difficult to produce large numbers of stem cells [51]. In comparison to adipose tissue and BM, in which MSCs are affected by donor's age, placenta is a rich source of stem cells [52] and high differentiation capacity and pluripotentiality of placental cells are related to their origin [53]. PD-MSCs have a higher proliferative potential than BM-MSCs [54] which reduces the number of passages to reach a large number of cells as well as the risk of cell aging $[55,56]$. Among MCSs, PD-MSCs have a higher potential for in vitro proliferation and differentiation of hepatocytes [57]. Human BM-MSC cells are involved in neovasculogenesis and synergize with endothelial colony forming cells (ECFCs) to create microvessels in vivo $[58,59]$. BMMSC cells serve as the gold standard for bone and cartilage repair [60]. Adipose tissue-derived mesenchymal stem cells (AD-MSCs) are isolated from adipose tissue by liposuction, are capable of differentiation to hepatocytelike cells in the presence of HGF, FGF-1, and FGF-4 factors and participate in the regeneration of hepatocytes and vasculogenesis [61]. Wharton's jelly mesenchymal stem cells (WJ-MSCs) exhibit stemness and pluripotential properties and have been shown to generate various types of neurons and connective tissue cells [62, 63].

Umbilical cord-derived mesenchymal stem cells (UCMSCs) have been recognized as low-immunogenicity cells because of their immunomodulatory properties. UC-MSCs are involved in neovascularization and differentiation into hepatocyte-like cells [64, 65]. Umbilical cord blood has always been considered as a source 
of hematopoietic stem cells (HSCs) [66]. The phenotypic characteristics of UC-MSCs are consistent with BMMSC cells [67].

Dental tissue-derived mesenchymal stem cells (DPMSC) have limited differentiation capacity relative to BM-MSCs [68]. Dental pulp stem cells (DPSCs) are dental stem and progenitor cells that are capable of selfrenewal and differentiation, which differentiate into neurons and adipocytes in addition to odontogenic cells [69, 70].

The definition of MSCs according to International Society for Cell Therapy (ISCT) is as follows: MSCs are (1) able to bind plastic surfaces, (2) able to differentiate into all three classes of chondrocytes, adipocytes and osteocytes in vitro, and (3) capable of expressing CD73, CD90, and CD105 markers but not hematopoietic markers like CD45, CD14, CD19, CD34, and HLADR [71]. MSCs release numerous factors such as vascular endothelial growth factor (VEGF), insulin-like growth factor 1 (IGF-1), basic fibroblast growth factor (bFGF), nerve growth factor (NGF), Transforming growth factor beta-1 (TGF-b1), placental growth factor (PGF), stromal cell-derived factor 1 (SDF-1/CXCL12), monocyte chemoattractant protein-1 (MCP 1/CCL2), hepatocyte growth factor (HGF), interleukin-6 (IL-6), IL-8, IL-10, IL-13, G-CSF and GM-CSF [72-75].

There are various tissue-specific factors in MSCs depending on the tissues from which MSCs are isolated. For example, factors such as HGF, bFGF, and IL-6 are mainly secreted by MSCs isolated from placental tissue or interferon- $\gamma$ (IFN- $\gamma$ ), tumor necrosis factor $\alpha$ (TNF$\alpha)$, interleukin-1 alpha (IL- $1 \alpha)$, and interleukin-1 beta (IL-1 $\beta$ ) secreted by MSCs from Menstrual blood-derived stem cells (MenSCs) [76, 77]. Hence, it can be said that the selection of mesenchymal stem cells extracted from tissues is an important consideration in the treatment of diseases with respect to the secretory factors they produce.

\section{Placenta-derived mesenchymal stem cells}

Embryonic stem cells are isolated from embryonic tissues, especially multiple extraembryonic tissues. Tissues such as amniotic fluid, Wharton's jelly, amnion, chorion, embryonic membrane and placenta have MSCs. The placenta is one of the largest organs with an essential role in the development of the fetus, which plays a role in the secretion of nutrients for the fetus and immune protection (tolerance) of it. It has recently been observed that PD-MSC are a new alternative source of MSCs for regenerative therapies [78]. Studies have shown that PD-MSCs possess self-renewal capacity, have multilineage differentiation, lack ethical problems, are accessible, abundant, and show strong immunosuppressive effects [79-81]). In addition, placental tissue derived from the fetus is voluminous and can be easily manipulated to increase the number of MSCs, which exceeds the number of MSCs present in bone marrow and adipose tissue [81, 82]. Another advantage of these placental stem cells is that we do not require an invasive method to isolate them, whereas invasive methods are needed to isolate adult MSCs [78].

Typically, PD-MSCs can maintain a high proliferative capacity in culture medium for at least 20 passages [83]. Some studies have recently suggested the differentiation of PD-MSCs into hepatocyte-like endodermal cells [57, 84]. Investigations have shown that many perinatal resources of MSCs such as amniotic membrane (AM), chorionic plate $(\mathrm{CP})$, parietal decidua [85], and umbilical cord (UC) have advantages relative to adult sources, including bone marrow (BM) [86-88]. The MSCs isolated from these tissues have their own characteristics as follows. VCAM1 is a biomarker of chorionic plate with unique immunosuppressive activity that plays an important role in immune responses [86]. CP-derived mesenchymal cells copiously secrete HGF and VCAM1. Parietal decidua derived mesenchymal stem cells (DMSCs) [85] show a high secretion of Ang1 and VEGF but the lowest secretion of TGF $\beta 1$. Umbilical cord (UC) derived MSCs have a high secretion level of IGF1 and amniotic membrane (AM) derived MSCs highly release PEG2 and TGF $\beta 1$ [89]. Considering the above statements, we show in this research that amniotic membrane-derived mesenchymal stem cells may be effective in treatment of premature ovarian aging due to overexpression of PEG2 and TGF $\beta 1$, CP-derived MSCs could be used for angiogenic therapy because of pro-angiogenic activity, and parietal decidua derived MSCS [85] might be useful for the treatment of vital organ ischemia, and UC-MSCs may be used for other therapies because of secreting a large number of factors [90].

\section{Possible disadvantages of MSCs}

Most animal and human studies on MSCs have indicated therapeutic effects of these cells. However, there is evidence for low engraftment of MSCs due to shortterm viability after injection $[77,91]$. MSCs are trapped in the lung after injection and a lower number of these cells may reach their destination [92]. Therefore, the reduction of cell loss during migration is an advantage of topical over intravenous injection [93]. Several studies have indicated that a single injection of MSCs is safe for the patient and does not stimulate the immune system, but re-injection of MSCs may lead to the generation of alloantibodies [94]. In addition, the FBS that is used to grow MSCs could induce an immune response in the patient [95]. In general, MSCs show a 
dual behavior when faced with tumors and PD-MSCs are no exception in this regard. For example, some in vitro studies have indicated that UC-MSCs increase the expression of proliferating cell nuclear antigen (PCNA) [96], induce the proliferation promoting genes like EPGN/MZT2A, downregulate transcription factors associated with the suppression of tumor development such as TAL1/FOS/EGR1/KLF10, which stimulates different tumor populations [97]. Pursuant to this dual role of PD-MSCs, one study introduces the antitumor role of these cells in a particular type of tumor but suggests a promoter role in another type. WJ-MSCs have an antitumor role in the face of squamous cell carcinoma in vitro, but stimulate the growth of cancer in vivo [98].

\section{Therapeutic approaches for acute liver failure \& PD-MSCs advantages}

Clinicians have observed that a number of patients with ALF may recover spontaneously and that the clinical outcome of these patients largely depends on the balance between loss and repair of hepatocytes [99]. The damaged hepatocytes are rapidly replaced by normal hepatocytes in moderate disease, but in case of severe injury and widespread death of hepatocytes, the repair capacity of remaining hepatocytes may not be complete and lead to the deployment of liver progenitor cells (LPC) that act as hepatocytes [100]. In most ALF patients, these progenitor cells are insufficient to repair and replace hepatocytes, eventually leading to the adoption of limited therapeutic approaches by physicians [101]. Today, liver transplantation is the only way to treat liver failure patients. However, liver transplantation has failed for a number of reasons such as lack of proper organs, high costs, and the administration of immunosuppressive agents for long periods of time. Other treatment strategies include bioartificial liver with less hepatocytes and drug therapy [102]. Hepatic failure is a disastrous consequence of liver loss, in which the repair of residual hepatocytes is not performed in a timely and appropriate manner, resulting in increased mortality [103]. Massive hepatic necrosis in acute liver failure [97] is caused by sudden loss of hepatocytes due to a variety of acute injuries induced by hepatotoxic drugs, immune system attack, and viral infections [104-106]. While most hepatocytes are completely destroyed in ALF, the circulating Bone Marrow-derived cells and endogenous hepatocyte progenitor cells can rapidly regenerate the liver [107]. Cell-based therapies have been promising in regenerative medicine. MSCs can be important sources of alternative therapy because of various properties such as self-renewal, proliferation and differentiation [108].

\section{Mechanisms of PD-MSC effect on acute liver injury}

The precise mechanism of MSCs in ALF is not completely understood [109]. According to several studies, it can be stated that placenta-derived mesenchymal stem cells (PD-MSC) are able to affect the liver damages in several ways:

1. PD-MSCs are recruited to the damaged area by VCAM-1 and VLA-4 adhesion molecules [104, 110, 111] affecting the remaining hepatocytes through cell-cell contact and secretion of TGF- $\alpha$, EGF, HGF, and VEGF tropic factors [112, 113].

2. PD-MSCs have immunomodulatory properties and increase Treg cells, modulating the immune system as well as suppressing activated T-cells, NK cells, B-cells and IL-10 production [113, 114].

3. PD-MSCs decrease the inflammation of hepatocytes and prevent their apoptosis by suppressing TNF $\alpha$ and IFN $\gamma$, which leads to the regeneration of hepatocytes by releasing HGF, IL-6, PAF and VEGF [115, 116].

4. MSCs are capable of secreting various angiogenic factors, including VEGF, SDF-1 $\alpha$, and MMP1, which promote angiogenesis [117-119].

5. In addition to their immunomodulatory properties, MCSs differentiate into vascular cells and pericytes in vivo [117]. They also have the potential to differentiate into hepatocyte-like cells both in vivo and in vitro, leading to improvement of liver damage (Fig. 1) [115, 120].

A majority of studies have used the intravenous route to inject MSCs, after which most MSCs are trapped in lungs in the early stages [121, 122]. After $24 \mathrm{~h}$, MSCs move toward other organs (especially the liver and spleen) and settle in them [123]. They also migrate to damaged tissues [123]. For instance, in a study on patients with cirrhosis, MSCs labeled with ${ }^{111} \mathrm{IN}$-Oxine were detected in the liver after $48 \mathrm{~h}$ (through radioactivity assay) where they remained for 10 days [124]. Elimination of MSCs may be related to the immune system, which does not rule out the functional effect of these cells. One study has reported that phagocytosis of dead MSCs induces the production of regulatory macrophages modulating the immune response by producing IL-10 factors $[125,126]$. Moreover, a small fraction of these cells that have been spared elimination could be responsible for the therapeutic effects [126].

MSCs play a critical role in liver regeneration because of their ability to produce and regulate platelet-activating factor (PAF), hepatocyte growth factor (HGF) and vascular endothelial growth factor (VEGF) [104]. Several studies have demonstrated the significance of MSCs in liver 


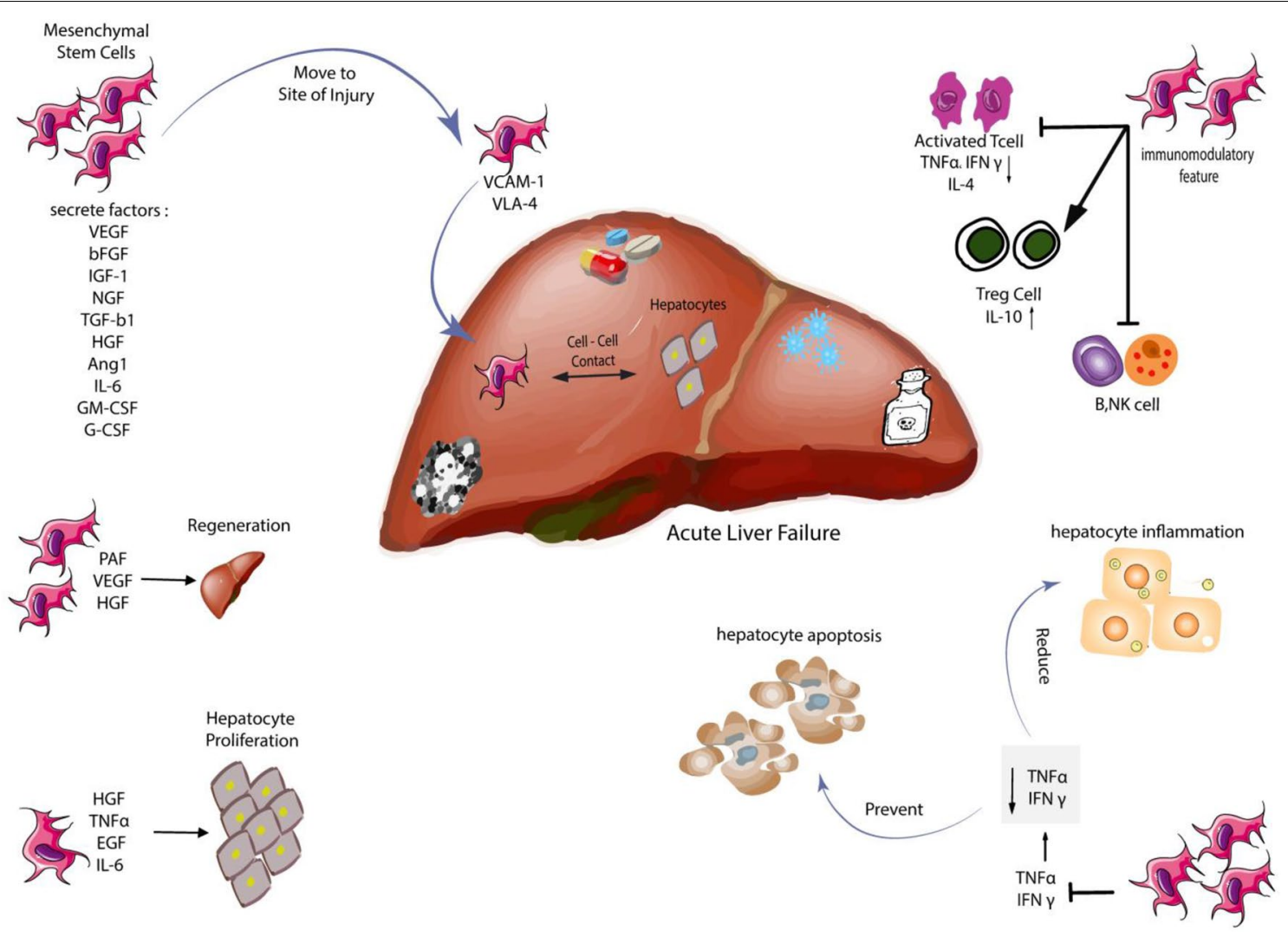

Fig. 1 Mesenchymal stem cells and its effects on acute liver failure

diseases. MSCs have been used in various investigations on ALF in both animal models $[127,128]$ and clinical trials $[129,130]$. Nevertheless, the precise mechanism of the function of these cells remains unclear. Since MSCs are able to move to the site of injury and inflammation [131] as well as being capable of proliferating and differentiating into hepatocytes $[132,133]$, they play an essential role in regenerative therapies. MSCs show immunomodulatory feature because they do not express stimulatory molecules or HLA II [134] and are therefore a good source for allogeneic and autologous transplantation.

Several studies have shown that MSCs secrete tropic factors and can be effective in reducing inflammation, fibrosis and apoptosis of liver cells as well as repairing damaged tissue by stimulating angiogenesis [74].

High migration ability is a major advantage of PDMSCs. Migration involves the movement of MSCs toward damaged and inflamed sites through interactions between MSCs with cytokines and adhesion molecules secreted from the injured tissue environment [135]. Migration of MSCs has been investigated in both animal [136] and in human studies [137]. For example, various researches have revealed that MSCs express adhesion molecules and integrins such as VCAM-1 and VLA-4, which are composed of CD29 and CD49d components. Compared with BM-derived mesenchymal stem cells (BM-MSCs), placental MSCs express a higher level of VLA-4 and animal studies have indicated MSCs binding to endothelial cell surface markers such as P-selectin and VCAM-1, which is indicative of the high implantation capacity of PD-MSCs into damaged tissue [111, 138]. A clinical trial of cirrhotic patients showed that ${ }^{111}$ In-oxinelabeled MSCs were trapped in the lungs in the early hours after injection through peripheral blood and that they left there after $48 \mathrm{~h}$ and migrated to the liver and spleen, remaining in these tissues for 10 days [137].

There are various mechanisms in the creation of an immunologically safe environment by placenta for the fetus [139]. This feature is a strong advantage for PDMSC cell therapy in allogeneic transplantation, which prevents graft rejection, stabilizes the transplant and drives MSCs, including BM-MSCs and amniotic fluidderived MSCs (AF-MSCS), toward the site of injury [140]. Embryonic-derived MSCs are also capable of migrating to the placenta and blood brain barrier (BBB) [141]. It can be argued that the beneficial effects of MSCs in liver diseases (including ALF) are not limited to hepatocyte repair, but rather the tropical factors released by 
them modulate the deleterious effects of the immune response [142]. The immunosuppressive effects of MSCs on the secretion of TNF $\alpha$ and IFN $\gamma$ prevent from apoptosis of hepatocyte cells and reduce hepatic inflammation, and the suppression of these cytokines appears to be systemic [143]. MSCS in mice with ALF suppress activated T-cells, decreasing the inflammatory cytokines TNF $\alpha, \gamma$ IFN and IL-4 and exerting their immunosuppressive effects by increasing IL-10 levels [143, 144]. Cells such as natural killer T (NKT) are of high importance in the pathogenesis of ALF and are immunomodulatory targets mediated by MSCs along with dendritic cells (DCs), macrophages and T-cells [143, 145].

HGF is one of the most important factors in the repair of hepatic tissue, which is secreted by MSCs. Hepatocyte growth factor is an effective mitogen for hepatic tissue repair that is dependent on c-met receptor during tissue damage [146]. The HGF/c-met signaling pathway is essential for liver repair and implantation of MSCs in the affected area [147]. Many studies have reported the protective effects of $\mathrm{HGF} / \mathrm{c}$-met signaling pathway on liver injury $[148,149]$. HGF as well as other factors like TNF $\alpha$ and EGF is considered a mitogenic factor associated with hepatocyte proliferation [112, 150]. On the other hand, HGF together with NGF factor secreted by MSCs induces apoptosis of Hepatocyte Stellate Cells (HSC), indicating the antifibrotic property of these cells [151153]. Many studies have shown that angiogenesis plays a crucial role in hepatic repair so that the injection of antiangiogenic factors such as anti-VEGF inhibits hepatic repair [154, 155] but factors such as bFGF enhance it [156]. VEGF boosts angiogenesis and contributes to the healing process [157]. Angiogenesis is essential for wound healing, regeneration and organogenesis [158]. IL-6 binds to gp 80 and gp130 receptors, which activate the JAK pathway and in turn phosphorylate tyrosines in the intracellular domain of gp130, subsequently activating the MAPK pathway and STAT 1 and 3 transcription factors that lead to hepatocyte proliferation [159-161]. Recent experiments on animal models have shown that IL- 6 and TNF- 2 are involved in regeneration of liver mass [162].

\section{Conclusion}

Limited information is available on the repair mechanism of MSCs in various diseases; therefore, further in vivo studies provide a broad perspective for MSCs use in clinical practice. Choosing the right cell, determining the proper dose, selecting the appropriate injection site and timely injection can help improve the function and implantation of MSCs in the target tissue, and they can be highly important and applicable for further research in the future. In this review paper, we concluded that
PD-MSCs can be considered as a good allogeneic source for ALF in future because of their safety, easy accessibility, lack of immune system stimulation, secretion of appropriate factors for liver tissue and healing properties.

\begin{abstract}
Abbreviations
MSCs: Mesenchymal stem cells; PD-MSCs: Placenta-derived mesenchymal stem cells; ALF: Acute liver failure; ACLF: Acute-on-chronic liver failure; CLF: Choronic liver failure; ICH: Intracranial hypertension; DAMPs: Damage-associated molecular patterns; SIRS: Systemic inflammatory response syndrome; CARS: Compensatory anti-inflammatory response syndrome; ISCT: International Society for Cell Therapy; VEGF: Vascular endothelial growth factor; IGF-1: Insulin-like growth factor 1; bFGF: Basic fibroblast growth factor; NGF: Nerve growth factor; TGF-b1: Transforming growth beta-1; IFN- - : Interferon- $\gamma$; TNF-a: Tumor necrosis factor a; IL-1a: Interleukin-1 alpha; IL-1 $\beta$ : Interleukin-1 beta; PGF: Placental growth factor; SDF-1/CXCL12: Stromal cell-derived factor 1; MCP 1/CCL2: Monocyte chemoattractant protein-1; HGF: Hepatocyte growth factor; G-CSF: Granulocyte-colony stimulating factor; GM-CSF: Granulocytemacrophage colony stimulating factor; AM: Amniotic membrane; CP: Chorionic plate; UC: Umbilical cord; LPC: Liver progenitor cells; PAF: Platelet-activating factor; VLA-4: Very late antigen 4; BBB: Blood brain barrier; HSC: Hepatocyte stellate cells; JAK: Janus kinase.
\end{abstract}

\section{Acknowledgements}

Not applicable.

\section{Authors' contributions}

$M S$, JV, and MNT contributed to the concept of the review. MS, JV, MK, AAS, $A A V, M N$, and $Z G, M K$ were responsible for the reference selection and writing of the manuscript. SA, MS, and AV contributed to the critical review of the manuscript. All authors read and approved the final manuscript.

\section{Funding}

This work was supported by the Tehran University of Medical Sciences

Availability of data and materials

Not applicable.

Ethics approval and consent to participate

Not applicable.

\section{Consent for publication}

Not applicable.

\section{Competing interests}

The authors declare that they have no competing interests.

\section{Author details}

${ }^{1}$ Department of Tissue Engineering and Applied Cell Sciences, School of Advanced Technologies in Medicine, Tehran University of Medical Sciences, Tehran, Iran. ${ }^{2}$ Gastroenterology and Hepatology, Tehran University of Medical Sciences, Imam Hospital Complex, Tehran, Iran. ${ }^{3}$ Gastroenterology and Hepatology, School of Medicine Shariati Hospital, Tehran University of Medical Science, Tehran, Iran. ${ }^{4}$ Department of Internal Medicine, School of Medicine, Alborz University of Medical Sciences, Karaj, Iran. ${ }^{5}$ Internal Medicine, School of Medicine Liver Transplantation Research Center Imam, Khomeini Hospital Tehran University of Medical Sciences, Tehran, Iran.

Received: 21 January 2020 Accepted: 16 May 2020

Published online: 24 May 2020

\section{References}

1. Rozemuller H, Prins HJ, Naaijkens B, Staal J, Buhring HJ, Martens AC. Prospective isolation of mesenchymal stem cells from multiple mammalian species using cross-reacting anti-human monoclonal antibodies. Stem Cells Dev. 2010;19(12):1911-21. 
2. Lee WM, Stravitz RT, Larson AM. Introduction to the revised American Association for the Study of Liver Diseases Position Paper on acute liver failure 2011. Hepatology. 2012;55(3):965-7.

3. Yu Y, Fisher JE, Lillegard JB, Rodysill B, Amiot B, Nyberg SL. Cell therapies for liver diseases. Liver transplantation : official publication of the American Association for the Study of Liver Diseases and the International Liver Transplantation Society. 2012;18(1):9-21.

4. Cai Y, Zou Z, Liu L, Chen S, Chen Y, Lin Z, et al. Bone marrow-derived mesenchymal stem cells inhibits hepatocyte apoptosis after acute liver injury. Int J Clin Exp Pathol. 2015;8(1):107-16.

5. Saliba F, Samuel D. Acute liver failure: current trends. J Hepatol. 2013;59(1):6-8.

6. Bernal W, Auzinger G, Dhawan A, Wendon J. Acute liver failure. Lancet. 2010;376(9736):190-201.

7. Cao Y, Zhang B, Lin R, Wang Q, Wang J, Shen F. Mesenchymal stem cell transplantation for liver cell failure: a new direction and option. Gastroenterol Res Pract. 2018;2018:10.

8. Rajaram P, Subramanian R. Acute liver failure. Semin Respir Crit Care Med. 2018;39(05):513-22.

9. Blackmore L, Bernal W. Acute liver failure. Clin Med. 2015;15(5):468-72

10. Cardoso FS, Marcelino P, Bagulho L, Karvellas CJ. Acute liver failure: an up-to-date approach. J Crit Care. 2017;39:25-30.

11. Kandiah PA, Olson JC, Subramanian RM. Emerging strategies for the treatment of patients with acute hepatic failure. Curr Opin Crit Care. 2016;22(2):142-51.

12. Bernal W, Auzinger G, Sizer E, Wendon J. Intensive care management of acute liver failure. Semin Liver Dis. 2008;28(2):188-200.

13. Bernsmeier C, Antoniades CG, Wendon J. What's new in acute liver failure? Intensive Care Med. 2014;40(10):1545-8.

14. O'Grady JG, Schalm SW, Williams R. Acute liver failure: redefining the syndromes. Lancet. 1993;342(8866):273-5.

15. Williams R. Classification, etiology, and considerations of outcome in acute liver failure. Semin Liver Dis. 1996;16(4):343-8.

16. Losser MR, Payen D. Mechanisms of liver damage. Semin Liver Dis. 1996;16(4):357-67.

17. Wendon J, Cordoba J, Dhawan A, Larsen FS, Manns M, Samuel D, et al. EASL Clinical Practical Guidelines on the management of acute (fulminant) liver failure. J Hepatol. 2017;66(5):1047-81.

18. Rolando N, Wade J, Davalos M, Wendon J, Philpott-Howard J, Williams $\mathrm{R}$. The systemic inflammatory response syndrome in acute liver failure. Hepatology. 2000;32(4 Pt 1):734-9.

19. Vaquero J, Fontana RJ, Larson AM, Bass NM, Davern TJ, Shakil AO, et al. Complications and use of intracranial pressure monitoring in patients with acute liver failure and severe encephalopathy. Liver Transpl. 2005;11(12):1581-9.

20. Sass DA, Shakil AO. Fulminant hepatic failure. Liver Transpl. 2005;11(6):594-605

21. Polson J, Lee WM. AASLD position paper: the management of acute liver failure. Hepatology. 2005;41(5):1179-97.

22. Bernal $\mathbf{W}$. Lactate is important in determining prognosis in acute liver failure. J Hepatol. 2010;53(1):209-10.

23. Ambrocio GPL, Aguado S, Carrillo J, Laporta R, Lazaro-Carrasco M, AvelIon $A$, et al. Hepatitis E virus infection in lung transplant recipients: a case series. Transpl Proc. 2019;51(2):376-9.

24. . Shah NJ, John S. Acute Liver Failure. StatPearls. Treasure Island (FL): StatPearls Publishing StatPearls Publishing LLC.; 2019

25. Gill RQ, Sterling RK. Acute liver failure. J Clin Gastroenterol. 2001:33(3):191-8.

26. Lee WM. Etiologies of acute liver failure. Semin Liver Dis. 2008;28(2):142-52.

27. Leber B, Spindelboeck W, Stadlbauer V. Infectious complications of acute and chronic liver disease. Semin Respir Crit Care Med. 2012;33(1):80-95.

28. Donnelly MC, Hayes PC, Simpson KJ. Role of inflammation and infection in the pathogenesis of human acute liver failure: clinical implications for monitoring and therapy. World J Gastroenterol. 2016;22(26):5958-70.

29. Amadi CN, Orisakwe OE. Herb-Induced Liver Injuries in Developing Nations: an Update. Toxics. 2018;6(2):24.

30. Sun C, Jin XL, Xiao JC. Oval cells in hepatitis B virus-positive and hepatitis $C$ virus-positive liver cirrhosis: histological and ultrastructural study. Histopathology. 2006;48(5):546-55.
31. Kopycinska J, Kempinska-Podhorodecka A, Haas T, Elias E, DePinho RA, Paik J, et al. Activation of FoxO3a/Bim axis in patients with Primary Biliary Cirrhosis. Liver Int. 2013;33(2):231-8.

32. Szabo G, Petrasek J. Inflammasome activation and function in liver disease. Nat Rev Gastroenterol Hepatol. 2015;12(7):387-400.

33. Kubes $P$, Mehal WZ. Sterile inflammation in the liver. Gastroenterology. 2012;143(5):1158-72.

34. Heymann F, Tacke F. Immunology in the liver-from homeostasis to disease. Nat Rev Gastroenterol Hepatol. 2016;13(2):88-110.

35. Szabo G, Csak T. Inflammasomes in liver diseases. J Hepatol. 2012;57(3):642-54

36. Woolbright $\mathrm{BL}$, Jaeschke $\mathrm{H}$. The impact of sterile inflammation in acute liver injury. J Clin Transl Res. 2017;3(Suppl 1):170-88.

37. Geiger A, Magnes J, Taylor RM, Veralli M. Effect of blood constituents on uptake of glucose and on metabolic rate of the brain in perfusion experiments. Am J Physiol. 1954;177(1):138-49.

38. Antoniades CG, Berry PA, Wendon JA, Vergani D. The importance of immune dysfunction in determining outcome in acute liver failure. J Hepatol. 2008;49(5):845-61.

39. Vaquero J, Chung C, Cahill ME, Blei AT. Pathogenesis of hepatic encephalopathy in acute liver failure. Semin Liver Dis. 2003;23(3):259-69.

40. Vaquero J, Polson J, Chung C, Helenowski I, Schiodt FV, Reisch J, et al. Infection and the progression of hepatic encephalopathy in acute liver failure. Gastroenterology. 2003;125(3):755-64.

41. Miyake Y, Yasunaka T, Ikeda F, Takaki A, Nouso K, Yamamoto K. SIRS score reflects clinical features of non-acetaminophen-related acute liver failure with hepatic coma. Intern Med. 2012;51(8):823-8.

42. Karvellas CJ, Pink F, McPhail M, Cross T, Auzinger G, Bernal W, et al. Predictors of bacteraemia and mortality in patients with acute liver failure. Intensive Care Med. 2009;35(8):1390-6.

43. Craig DG, Reid TW, Martin KG, Davidson JS, Hayes PC, Simpson KJ. The systemic inflammatory response syndrome and sequential organ failure assessment scores are effective triage markers following paracetamol (acetaminophen) overdose. Aliment Pharmacol Ther. 2011;34(2):219-28.

44. Murray PJ, Allen JE, Biswas SK, Fisher EA, Gilroy DW, Goerdt S, et al. Macrophage activation and polarization: nomenclature and experimental guidelines. Immunity. 2014;41(1):14-20.

45. Xue J, Schmidt SV, Sander J, Draffehn A, Krebs W, Quester I, et al. Transcriptome-based network analysis reveals a spectrum model of human macrophage activation. Immunity. 2014:40(2):274-88.

46. Bleriot C, Dupuis T, Jouvion G, Eberl G, Disson O, Lecuit M. Liver-resident macrophage necroptosis orchestrates type 1 microbicidal inflammation and type-2-mediated tissue repair during bacterial infection. Immunity. 2015;42(1):145-58.

47. Garcia-Martinez I, Santoro N, Chen Y, Hoque R, Ouyang X, Caprio S, et al. Hepatocyte mitochondrial DNA drives nonalcoholic steatohepatitis by activation of TLR9. J Clin Investig. 2016;126(3):859-64.

48. Horwitz EM, Keating A. Nonhematopoietic mesenchymal stem cells: what are they? Cytotherapy. 2000;2(5):387-8.

49. Yao B, Huang S, Gao D, Xie J, Liu N, Fu X. Age-associated changes in regenerative capabilities of mesenchymal stem cell: impact on chronic wounds repair. Int Wound J. 2016;13(6):1252-9.

50. Lin $\mathrm{H}$. The stem-cell niche theory: lessons from flies. Nat Rev Genet. 2002;3(12):931-40.

51. de la Torre P, Pérez-Lorenzo M, Flores Al. Human placenta-derived mesenchymal stromal cells: a review from basic research to clinical applications. In: Stromal cells. Rijeka: IntechOpen; 2019. https://doi. org/10.5772/intechopen.76718.

52. Shigeno $Y$, Ashton BA. Human bone-cell proliferation in vitro decreases with human donor age. J Bone Jt Surg Br Vol. 1995;77(1):139-42.

53. Macias MI, Grande J, Moreno A, Domínguez I, Bornstein R, Flores Al. Isolation and characterization of true mesenchymal stem cells derived from human term decidua capable of multilineage differentiation into all 3 embryonic layers. Am J Obstet Gynecol. 2010;203(5):495.e9.

54. Barlow S, Brooke G, Chatterjee K, Price G, Pelekanos R, Rossetti T, et al. Comparison of human placenta- and bone marrow-derived multipotent mesenchymal stem cells. Stem Cells Dev. 2008;17:1095-107. 
55. Bork S, Pfister S, Witt H, Horn P, Korn B, Ho AD, et al. DNA methylation pattern changes upon long-term culture and aging of human mesenchymal stromal cells. Aging Cell. 2010;9(1):54-63.

56. Wagner W, Bork S, Horn P, Krunic D, Walenda T, Diehlmann A, et al. Aging and replicative senescence have related effects on human stem and progenitor cells. PLOS ONE. 2009;4(6):e5846.

57. Lee HJ, Jung J, Cho KJ, Lee CK, Hwang SG, Kim GJ. Comparison of in vitro hepatogenic differentiation potential between various placenta-derived stem cells and other adult stem cells as an alternative source of functional hepatocytes. Differ Res Biol Divers. 2012;84(3):223-31.

58. Rohban R, Etchart N, Pieber TR. Vasculogenesis Potential of Mesenchymal and Endothelial Stem Cells Isolated from Various Human Tissues. bioRxiv. 2016:049668.

59. Rohban R, Etchart N, Pieber TR. Transplantation of Endothelial Progenitor Cells Solely Leads to Development of Functional Neo-vessels. bioRxiv. 2016:049650.

60. Liu G, Li Y, Sun J, Zhou H, Zhang W, Cui L, et al. In vitro and In vivo evaluation of osteogenesis of human umbilical cord blood-derived mesenchymal stem cells on partially demineralized bone matrix. Tissue Eng Part A. 2009;16(3):971-82.

61. Banaś-Ząbczyk A, Teratani T, Yamamoto Y, Tokuhara M, Takeshita F, Quinn G, et al. Adipose tissue-derived mesenchymal stem cells as a source of human hepatocytes. Hepatol. 2007;46:219-28.

62. Wang H-S, Hung S-C, Peng S-T, Huang C-C, Wei H-M, Guo Y-J, et al. Mesenchymal stem cells in the Wharton's Jelly of the human umbilical cord. Stem Cells. 2004:22(7):1330-7.

63. Kalaszczynska I, Ferdyn K. Wharton's Jelly derived mesenchymal stem cells: future of regenerative medicine? Recent findings and clinical significance. Biomed Res Int. 2015;2015:430847.

64. Goren A, Dahan N, Goren E, Baruch L, Machluf M. Encapsulated human mesenchymal stem cells: a unique hypoimmunogenic platform for long-term cellular therapy. FASEB J. 2009;24(1):22-31.

65. Zhao Q, Ren H, Li X, Chen Z, Zhang X, Gong W, et al. Differentiation of human umbilical cord mesenchymal stromal cells into low immunogenic hepatocyte-like cells. Cytotherapy. 2009;11(4):414-26.

66. Broxmeyer H, Douglas G, Hangoc G, Cooper S, Bard J, English D, et al. Human umbilical cord blood as a potential source of transplantable hematopoietic stem/progenitor cells. Proc Natl Acad Sci USA. 1989;86:3828-32.

67. Mareschi K, Biasin E, Piacibello W, Aglietta M, Madon E, Fagioli F. Isolation of human mesenchymal stem cells: bone marrow versus umbilical cord blood. Haematologica. 2001;86:1099-100.

68. Huang G, Gronthos S, Shi S. Mesenchymal stem cells derived from dental tissues vs. those from other sources: their biology and role in regenerative medicine. J Dent Res. 2009;88:792-806.

69. Tatullo M, Marrelli M, Shakesheff KM, White LJ. Dental pulp stem cells: function, isolation and applications in regenerative medicine. J Tissue Eng Regen Med. 2015;9(11):1205-16.

70. Gronthos S, Brahim J, Li W, Fisher LW, Cherman N, Boyde A, et al. Stem cell properties of human dental pulp stem cells. J Dent Res. 2002;81(8):531-5.

71. Dominici M, Le Blanc K, Mueller I, Slaper-Cortenbach I, Marini F, Krause D, et al. Minimal criteria for defining multipotent mesenchymal stromal cells. The International Society for Cellular Therapy position statement. Cytotherapy. 2006;8(4):315-7.

72. Majumdar MK, Thiede MA, Haynesworth SE, Bruder SP, Gerson SL. Human marrow-derived mesenchymal stem cells (MSCs) express hematopoietic cytokines and support long-term hematopoiesis when differentiated toward stromal and osteogenic lineages. J Hematother Stem Cell Res. 2000;9(6):841-8.

73. Schinkothe T, Bloch W, Schmidt A. In vitro secreting profile of human mesenchymal stem cells. Stem Cells Dev. 2008;17(1):199-206.

74. Kupcova Skalnikova H. Proteomic techniques for characterisation of mesenchymal stem cell secretome. Biochimie. 2013;95(12):2196-211.

75. Cao X-F, Jin S-Z, Sun L, Zhan Y-B, Lin F, Li Y, et al. Therapeutic effects of hepatocyte growth factor-overexpressing dental pulp stem cells on liver cirrhosis in a rat model. Sci Rep. 2017;7(1):15812.

76. Du WJ, Chi Y, Yang ZX, Li ZJ, Cui JJ, Song BQ, et al. Heterogeneity of proangiogenic features in mesenchymal stem cells derived from bone marrow, adipose tissue, umbilical cord, and placenta. Stem Cell Res Ther. 2016;7(1):163.

77. Wang Y, Chen X, Cao W, Shi Y. Plasticity of mesenchymal stem cells in immunomodulation: pathological and therapeutic implications. Nat Immunol. 2014;15(11):1009-16.

78. Kim GJ. Advanced research on stem cell therapy for hepatic diseases: potential implications of a placenta-derived mesenchymal stem cellbased strategy. Hanyang Med Rev. 2015;35(4):207-14.

79. Fukuchi Y, Nakajima H, Sugiyama D, Hirose I, Kitamura T, Tsuji K. Human placenta-derived cells have mesenchymal stem/progenitor cell potential. Stem Cells. 2004;22(5):649-58.

80. Anker PS, Scherjon SA, Kleijburg-van der Keur C, de Groot-Swings GM, Claas FH, Fibbe WE, et al. Isolation of mesenchymal stem cells of fetal or maternal origin from human placenta. Stem Cells. 2004;22(7):1338-45.

81. Kim MJ, Shin KS, Jeon JH, Lee DR, Shim SH, Kim JK, et al. Human chorionic-plate-derived mesenchymal stem cells and Wharton's jelly-derived mesenchymal stem cells: a comparative analysis of their potential as placenta-derived stem cells. Cell Tissue Res. 2011;346(1):53-64.

82. Marcus AJ, Woodbury D. Fetal stem cells from extra-embryonic tissues: do not discard. J Cell Mol Med. 2008;12(3):730-42.

83. Parolini O, Alviano F, Bagnara GP, Bilic G, Buhring HJ, Evangelista M, et al. Concise review: isolation and characterization of cells from human term placenta: outcome of the first international workshop on placenta derived stem cells. Stem Cells. 2008;26(2):300-11.

84. Lee H-J, Cha KE, Hwang S-G, Kim JK, Kim GJ. vitro screening system for hepatotoxicity: comparison of bone-marrow-derived mesenchymal stem cells and Placenta-derived stem cells. J Cell Biochem. 2011;112(1):49-58.

85. Mohamadnejad M, Ashrafi M, Alimoghaddam K, Vosough M, Mardpour S, Azimian V, et al. Surveillance for hepatocellular carcinoma after autologous stem cell transplantation in cirrhosis. Middle East J Dig Dis. 2012:4(3):145-9.

86. Yang ZX, Han Z-B, Ji YR, Wang YW, Liang L, Chi Y, et al. CD106 Identifies a subpopulation of mesenchymal stem cells with unique immunomodulatory properties. PLoS ONE. 2013;8(3):e59354.

87. Ilancheran S, Moodley Y, Manuelpillai U. Human fetal membranes: a source of stem cells for tissue regeneration and repair? Placenta. 2009;30(1):2-10.

88. Abumaree MH, Abomaray FM, Alshehri NA, Almutairi A, AlAskar AS, Kalionis $B$, et al. Phenotypic and functional characterization of mesenchymal stem/multipotent stromal cells from decidua parietalis of human term placenta. Reprod Sci. 2016;23(9):1193-207.

89. Wu M, Zhang R, Zou Q, Chen Y, Zhou M, Li X, et al. Comparison of the biological characteristics of mesenchymal stem cells derived from the human placenta and umbilical cord. Sci Rep. 2018;8:5014.

90. Gonzalez PL, Carvajal C, Cuenca J, Alcayaga-Miranda F, Figueroa FE, Bartolucci J, et al. Chorion mesenchymal stem cells show superior differentiation, immunosuppressive, and angiogenic potentials in comparison with haploidentical maternal placental cells. Stem Cells Transl Med. 2015;4(10):1 109-21.

91. Bahr L, Batsis I, Moll G, Hägg M, Szakos A, Sundberg B, et al. Analysis of tissues following mesenchymal stromal cell therapy in humans indicates limited long-term engraftment and no ectopic tissue formation. Stem Cells. 2012;30:1575-8.

92. Makela T, Takalo R, Arvola O, Haapanen H, Yannopoulos F, Blanco $R$, et al. Safety and biodistribution study of bone marrow-derived mesenchymal stromal cells and mononuclear cells and the impact of the administration route in an intact porcine model. Cytotherapy. 2015;17(4):392-402.

93. Kim I, Bang SI, Lee SK, Park SY, Kim M, Ha H. Clinical implication of allogenic implantation of adipogenic differentiated adipose-derived stem cells. Stem Cells Transl Med. 2014;3(11):1312-21.

94. Cho PS, Messina DJ, Hirsh EL, Chi N, Goldman SN, Lo DP, et al. Immunogenicity of umbilical cord tissue derived cells. Blood. 2008;111(1):430-8.

95. von Bonin M, Stolzel F, Goedecke A, Richter K, Wuschek N, Holig K, et al. Treatment of refractory acute GVHD with third-party MSC expanded in platelet lysate-containing medium. Bone Marrow Transpl. 2009;43:245.

96. Li T, Zhang C, Ding Y, Zhai W, Liu K, Bu F, et al. Umbilical cord-derived mesenchymal stem cells promote proliferation and migration in MCF-7 and MDA-MB-231 breast cancer cells through activation of the ERK pathway. Oncol Rep. 2015;34(3):1469-77. 
97. Yang Y, Otte A, Hass R. Human mesenchymal stroma/stem cells exchange membrane proteins and alter functionality during interaction with different tumor cell lines. Stem Cells Dev. 2015;24(10):1205-22.

98. Vulcano F, Milazzo L, Ciccarelli C, Eramo A, Sette G, Mauro A, et al. Wharton's jelly mesenchymal stromal cells have contrasting effects on proliferation and phenotype of cancer stem cells from different subtypes of lung cancer. Exp Cell Res. 2016;345(2):190-8.

99. Best J, Dolle L, Manka P, Coombes J, van Grunsven LA, Syn WK. Role of liver progenitors in acute liver injury. Front Physiol. 2013;4:258.

100. Preziosi ME, Monga SP. Update on the mechanisms of liver regeneration. Semin Liver Dis. 2017;37(2):141-51.

101. Sang JF, Shi XL, Han B, Huang T, Huang X, Ren HZ, et al. Intraportal mesenchymal stem cell transplantation prevents acute liver failure through promoting cell proliferation and inhibiting apoptosis. Hepatobil Pancreat Dis Int. 2016;15(6):602-11.

102. Basto S, Villela-Nogueira C, Tura B, Coelho H, Ribeiro J, Fernandes E, et al. Risk Factors for Long-Term Mortality in a Large Cohort of Patients WaitListed for Liver Transplantation in Brazil. Liver Transpl. 2011;17:1013-20.

103. Saunders SJ, Hickman R, Macdonald R, Terblanche J. The treatment of acute liver failure. Prog Liver Dis. 1972;4:333-44.

104. Putra A, Antari A, RetnoKustiyah A, SorayaNurlntan Y, Anna C, Sadyah N, Wirawan $\mathrm{N}$, et al. Mesenchymal stem cells accelerate liver regeneration in acute liver failure animal model. Biomed Res Ther. 2018;5:2802-10.

105. Wang Y-H, Wu D-B, Chen B, Chen E-Q, Tang H. Progress in mesenchymal stem cell-based therapy for acute liver failure. Stem Cell Res Ther. 2018;9(1):227.

106. Krysko DV, Denecker G, Festjens N, Gabriels S, Parthoens E, D'Herde K, et al. Macrophages use different internalization mechanisms to clear apoptotic and necrotic cells. Cell Death Differ. 2006;13(12):2011-22.

107. Itoh T, Miyajima A. Liver regeneration by stem/progenitor cells. Hepatology. 2014;59(4):1617-26.

108. Bianco P, Robey PG, Simmons PJ. Mesenchymal stem cells: revisiting history, concepts, and assays. Cell Stem Cell. 2008;2(4):313-9.

109. You Y, Wen DG, Gong JP, Liu ZJ. Research status of mesenchymal stem cells in liver transplantation. Cell Transpl. 2019;28(12):1490-506.

110. Henschler R, Deak E, Seifried E. Homing of mesenchymal stem cells. Transfus Med Hemother. 2008;35(4):306-12.

111. Karlsson H, Erkers T, Nava S, Ruhm S, Westgren M, Ringden O. Stromal cells from term fetal membrane are highly suppressive in allogeneic settings in vitro. Clin Exp Immunol. 2012;167(3):543-55.

112. Michalopoulos GK. Liver regeneration after partial hepatectomy: critical analysis of mechanistic dilemmas. Am J Pathol. 2010;176(1):2-13.

113. Eom YW, Shim KY, Baik SK. Mesenchymal stem cell therapy for liver fibrosis. Korean J Intern Med. 2015;30(5):580-9.

114. Zagoura D, Trohatou O, Makridakis M, Kollia A, Kokla N, Mokou M, et al. Functional secretome analysis reveals Annexin-A1 as important paracrine factor derived from fetal mesenchymal stem cells in hepatic regeneration. EBioMedicine. 2019;45:542-52.

115. Zhang GZ, Sun HC, Zheng LB, Guo JB, Zhang XL. In vivo hepatic differentiation potential of human umbilical cord-derived mesenchymal stem cells: therapeutic effect on liver fibrosis/cirrhosis. World J Gastroenterol. 2017;23(46):8152-68.

116. Fiore EJ, Bayo JM, Garcia MG, Malvicini M, Lloyd R, Piccioni F, et al. Mesenchymal stromal cells engineered to produce IGF-I by recombinant adenovirus ameliorate liver fibrosis in mice. Stem Cells Dev. 2015;24(6):791-801

117. Jiang Y-C, Wang X-F, Xu Y-Y, Qiao Y-H, Guo X, Wang D-F, et al. Polycaprolactone nanofibers containing vascular endothelial growth factor-encapsulated gelatin particles enhance mesenchymal stem cell differentiation and angiogenesis of endothelial cells. Biomacromol. 2018;19(9):3747-53.

118. Kuchroo P, Dave V, Vijayan A, Viswanathan C, Ghosh D. Paracrine factors secreted by umbilical cord-derived mesenchymal stem cells induce angiogenesis in vitro by a VEGF-independent pathway. Stem Cells Dev. 2014;24(4):437-50.

119. Boomsma R, Geenen D. Mesenchymal stem cells secrete multiple cytokines that promote angiogenesis and have contrasting effects on chemotaxis and apoptosis. PLoS ONE. 2012;7:e35685.

120. Guo Y, Chen B, Chen L-J, Zhang C-F, Xiang C. Current status and future prospects of mesenchymal stem cell therapy for liver fibrosis. J Zhejiang Univ Sci B. 2016;17(11):831-41.
121. Eggenhofer E, Benseler V, Kroemer A, Popp FC, Geissler EK, Schlitt $\mathrm{HJ}$, et al. Mesenchymal stem cells are short-lived and do not migrate beyond the lungs after intravenous infusion. Front Immunol. 2012;3:297.

122. Assis ACM, Carvalho JL, Jacoby BA, Ferreira RLB, Castanheira P, Diniz SOF, et al. Time-dependent migration of systemically delivered bone marrow mesenchymal stem cells to the infarcted heart. Cell Transpl. 2010;19(2):219-30.

123. Kraitchman D, Tatsumi M, Gilson W, Ishimori T, Kedziorek D, Walczak P, et al. Dynamic imaging of allogeneic mesenchymal stem cells trafficking to myocardial infarction. Circulation. 2005;112:1451-61.

124. Mirpour S, Gholamrezanezhad A, Saghari M, Malekzadeh R. In vivo tracking of 111 In-Oxine labeled mesenchymal stem cells following infusion in patients with advanced cirrhosis. Zeitschrift für Gastroenterologie. 2009;47:P127.

125. Lu W, Fu C, Song L, Yao Y, Zhang X, Chen Z, et al. Exposure to supernatants of macrophages that phagocytized dead mesenchymal stem cells improves hypoxic cardiomyocytes survival. Int J Cardiol. 2012;165:333-40.

126. Eggenhofer E, Luk F, Dahlke MH, Hoogduijn MJ. The Life and Fate of Mesenchymal Stem Cells. Front Immunol. 2014;5:148.

127. Li J, Zhang L, Xin J, Jiang L, Li J, Zhang T, et al. Immediate intraportal transplantation of human bone marrow mesenchymal stem cells prevents death from fulminant hepatic failure in pigs. Hepatology. 2012;56(3):1044-52.

128. Cao H, Yang J, Yu J, Pan Q, Li J, Zhou P, et al. Therapeutic potential of transplanted placental mesenchymal stem cells in treating Chinese miniature pigs with acute liver failure. BMC Med. 2012;10:56.

129. Shi M, Zhang Z, Xu R, Lin H, Fu J, Zou Z, et al. Human mesenchymal stem cell transfusion is safe and improves liver function in acute-onchronic liver failure patients. Stem Cells Transl Med. 2012;1(10):725-31.

130. El-Ansary M, Abdel-Aziz I, Mogawer S, Abdel-Hamid S, Hammam O, Teaema S, et al. Phase II trial: undifferentiated versus differentiated autologous mesenchymal stem cells transplantation in Egyptian patients with HCV induced liver cirrhosis. Stem Cell Rev Rep. 2012;8(3):972-81.

131. Leibacher J, Henschler R. Biodistribution, migration and homing of systemically applied mesenchymal stem/stromal cells. Stem Cell Res Ther. 2016;7:7.

132. Christ B, Bruckner S, Winkler S. The therapeutic promise of mesenchymal stem cells for liver restoration. Trends Mol Med. 2015;21(11):673-86.

133. Pournasr B, Mohamadnejad M, Bagheri M, Aghdami N, Shahsavani M, Malekzadeh $\mathrm{R}$, et al. In vitro differentiation of human bone marrow mesenchymal stem cells into hepatocyte-like cells. Arch Iran Med. 2011;14(4):244-9.

134. Singer NG, Caplan Al. Mesenchymal stem cells: mechanisms of inflammation. Annu Rev Pathol. 2011;6:457-78.

135. Schultz KM, Kyburz KA, Anseth KS. Measuring dynamic cell-material interactions and remodeling during 3D human mesenchymal stem cell migration in hydrogels. Proc Natl Acad Sci USA. 2015;112(29):E3757-64.

136. Li Q, Zhou X, Shi Y, Li J, Zheng L, Cui L, et al. In vivo tracking and comparison of the therapeutic effects of MSCs and HSCs for liver injury. PLOS ONE. 2013;8(4):e62363.

137. Gholamrezanezhad A, Mirpour S, Bagheri M, Mohamadnejad M, Alimoghaddam K, Abdolahzadeh L, et al. In vivo tracking of 111 In-oxine labeled mesenchymal stem cells following infusion in patients with advanced cirrhosis. Nucl Med Biol. 2011;38(7):961-7.

138. Rüster B, Göttig S, Ludwig R, Bistrian R, Müller S, Seifried E, et al. Mesenchymal stem cells display coordinated rolling and adhesion behavior on endothelial cells. Blood. 2007;108:3938-44.

139. Fujisaki J, Wu J, Carlson AL, Silberstein L, Putheti P, Larocca R, et al. In vivo imaging of Treg cells providing immune privilege to the haematopoietic stem-cell niche. Nature. 2011;474(7350):216-9.

140. Yagi H, Soto-Gutierrez A, Parekkadan B, Kitagawa Y, Tompkins RG, Kobayashi N, et al. Mesenchymal stem cells: mechanisms of immunomodulation and homing. Cell Transpl. 2010;19(6):667-79.

141. Dawe GS, Tan XW, Xiao ZC. Cell migration from baby to mother. Cell Adh Migr. 2007;1(1):19-27.

142. Gazdic M, Arsenijevic A, Markovic BS, Volarevic A, Dimova I, Djonov V, et al. Mesenchymal stem cell-dependent modulation of liver diseases. Int J Biol Sci. 2017;13(9):1109-17. 
143. Heymann F, Hamesch K, Weiskirchen R, Tacke F. The concanavalin A model of acute hepatitis in mice. Lab Anim. 2015;49(1 Suppl):12-20.

144. Ryu KH, Kim SY, Kim YR, Woo SY, Sung SH, Kim HS, et al. Tonsil-derived mesenchymal stem cells alleviate concanavalin A-induced acute liver injury. Exp Cell Res. 2014;326(1):143-54.

145. Higashimoto M, Sakai Y, Takamura M, Usui S, Nasti A, Yoshida K, et al. Adipose tissue derived stromal stem cell therapy in murine ConAderived hepatitis is dependent on myeloid-lineage and CD4+T-cell suppression. Eur J Immunol. 2013;43(11):2956-68.

146. Trusolino L, Bertotti A, Comoglio PM. MET signalling: principles and functions in development, organ regeneration and cancer. Nat Rev Mol Cell Biol. 2010;11(12):834-48.

147. Liu J, Pan G, Liang T, Huang P. HGF/c-Met signaling mediated mesenchymal stem cell-induced liver recovery in intestinal ischemia reperfusion model. International journal of medical sciences. 2014;11(6):626-33.

148. Huh CG, Factor VM, Sanchez A, Uchida K, Conner EA, Thorgeirsson SS. Hepatocyte growth factor/c-met signaling pathway is required for efficient liver regeneration and repair. Proc Natl Acad Sci USA. 2004:101(13):4477-82.

149. López-Islas A, Chagoya-Hazas V, Pérez-Aguilar B, Palestino-Domínguez M, Souza V, Miranda RU, et al. Cholesterol enhances the toxic effect of ethanol and acetaldehyde in primary mouse hepatocytes. Oxid Med Cell Longev. 2016;2016:9209825.

150. Hu Z, Evarts RP, Fujio K, Marsden ER, Thorgeirsson SS. Expression of hepatocyte growth factor and c-met genes during hepatic differentiation and liver development in the rat. Am J Pathol. 1993;142(6):1823-30.

151. Parekkadan B, van Poll D, Megeed Z, Kobayashi N, Tilles AW, Berthiaume F, et al. Immunomodulation of activated hepatic stellate cells by mesenchymal stem cells. Biochem Biophys Res Commun. 2007;363(2):247-52.

152. Wang J, Bian C, Liao L, Zhu Y, Li J, Zeng L, et al. Inhibition of hepatic stellate cells proliferation by mesenchymal stem cells and the possible mechanisms. Hepatol Res. 2009;39(12):1219-28.

153. Lin N, Hu K, Chen S, Xie S, Tang Z, Lin J, et al. Nerve growth factormediated paracrine regulation of hepatic stellate cells by multipotent mesenchymal stromal cells. Life Sci. 2009;85(7-8):291-5.
154. Taniguchi E, Sakisaka S, Matsuo K, Tanikawa K, Sata M. Expression and role of vascular endothelial growth factor in liver regeneration after partial hepatectomy in rats. J Histochem Cytochem. 2001;49(1):121-30.

155. Drixler TA, Vogten MJ, Ritchie ED, van Vroonhoven TJ, Gebbink MF, Voest $\mathrm{EE}$, et al. Liver regeneration is an angiogenesis-associated phenomenon. Ann Surg. 2002;236(6):703-11.

156. Greene AK, Wiener S, Puder M, Yoshida A, Shi B, Perez-Atayde AR, et al. Endothelial-directed hepatic regeneration after partial hepatectomy. Ann Surg. 2003:237(4):530-5.

157. Li WL, Su J, Yao YC, Tao XR, Yan YB, Yu HY, et al. Isolation and characterization of bipotent liver progenitor cells from adult mouse. Stem Cells. 2006;24(2):322-32.

158. Uda Y, Hirano T, Son G, limuro Y, Uyama N, Yamanaka J, et al. Angiogenesis is crucial for liver regeneration after partial hepatectomy. Surgery. 2013;153(1):70-7.

159. Cressman DE, Greenbaum LE, DeAngelis RA, Ciliberto G, Furth EE, Poli V et al. Liver failure and defective hepatocyte regeneration in interleukin6-deficient mice. Science. 1996;274(5291):1379-83.

160. Talarmin H, Rescan C, Cariou S, Glaise D, Zanninelli G, Bilodeau M, et al. The mitogen-activated protein kinase kinase/extracellular signal-regulated kinase cascade activation is a key signalling pathway involved in the regulation of $\mathrm{G}(1)$ phase progression in proliferating hepatocytes. Mol Cell Biol. 1999;19(9):6003-11.

161. Heinrich PC, Behrmann I, Muller-Newen G, Schaper F, Graeve L. Interleukin-6-type cytokine signalling through the gp130/Jak/STAT pathway. Biochem J. 1998;334(Pt 2):297-314.

162. Trautwein C, Rakemann T, Niehof M, Rose-John S, Manns MP. Acutephase response factor, increased binding, and target gene transcription during liver regeneration. Gastroenterology. 1996;110(6):1854-62.

\section{Publisher's Note}

Springer Nature remains neutral with regard to jurisdictional claims in published maps and institutional affiliations.
Ready to submit your research? Choose BMC and benefit from:

- fast, convenient online submission

- thorough peer review by experienced researchers in your field

- rapid publication on acceptance

- support for research data, including large and complex data types

- gold Open Access which fosters wider collaboration and increased citations

- maximum visibility for your research: over $100 \mathrm{M}$ website views per year

At $\mathrm{BMC}$, research is always in progress.

Learn more biomedcentral.com/submissions 